\title{
Heavy metals in livers of raptors from Eastern Poland - the importance of diet composition
}

\section{Ignacy Kitowski 1,*, Agnieszka Sujak ${ }^{2}$, Dariusz Wiącek ${ }^{3}$, Wacław Strobel ${ }^{3}$, Andrzej Komosa ${ }^{4}$, Marcin Stobiński ${ }^{5}$}

\footnotetext{
1 State School of Higher Education in Chełm, Pocztowa 54, 22-100 Chełm, Poland.

2 Department of Biophysics, University of Life Sciences in Lublin, Akademicka 13, 20-930 Lublin, Poland.

3 Institute of Agrophysics, Polish Academy of Sciences, Doświadczalna 4, 20-290 Lublin, Poland.

4 Department of Radiochemistry and Colloid Chemistry, Maria Curie-Skłodowska University, Pl. M. C. Skłodowskiej 3, 20-031 Lublin, Poland.

5 Faculty of Energy and Fuels, AGH University of Science and Technology, Al. Mickiewicza 30, $30-059$ Kraków, Poland.

*Corresponding author: ignacyk@autograf.pl
}

\begin{abstract}
Concentrations of $\mathrm{Pb}, \mathrm{Cd}, \mathrm{Ni}, \mathrm{Cr}$ and $\mathrm{Hg}$ were determined in livers of six species of raptors collected in the area of Eastern Poland. Redundancy analysis (RDA) showed that elevated $\mathrm{Hg}$ and $\mathrm{Cr}$ concentrations were directly related to feeding on passerines. Raptors that specialised in seizing small mammals as a source of food revealed higher hepatic concentrations of $\mathrm{Pb}$ and $\mathrm{Cd}$ in comparison with other raptors. Unlike $\mathrm{Cd}$, we found statistically significant differences in the $\mathrm{Pb}$ concentrations in livers of Common buzzards as compared to Sparrowhawks. In spite of the fact that both Goshawks and Sparrowhawks hunt birds, only the latter species had accumulated significantly more mercury. The high concentrations of Hg in Sparrowhawks could be related to the use of mercury in antifungal substances for seed dressing.
\end{abstract}

KEY WORDS: raptors, liver, heavy metals, lead bullets.

\section{INTRODUCTION}

In spite of extensive surveys, many aspects of heavy metal accumulation and transmission in ecosystems remain unclear (HELANDER et al., 2009; STANKOVIC et al., 2013; KITOWSKI et al., 2014). Exposure to high levels of heavy metals through diet or other activities can have toxic effects on avian species influencing their hormone and respiratory systems, reproduction and migration (SCHEUHAMMER 1987; HASCHEK et al., 2013; WiLLiAMs et al., 2014). Raptors seem to be especially well-suited models for investigating these processes in birds as top predators in food chains, because they also have a wide geographical distribution and are often sedentary (MARTIN et al., 2008; CASTRO et al., 2011; RAJAMANI \& SUBRAMANIAN, 2015; GOLDEN et al., 2016 ). It has been pointed out that metal concentrations in birds are good indicators of the level of heavy metal concentration in their diet, which is strongly associated with the degree of contamination in the exploited ecosystem (PAIN et al., 1997; CASTRO et al., 2011). Eastern European countries are unfortunately prominent in heavy metal $(\mathrm{Pb}, \mathrm{Cd}, \mathrm{Ni}, \mathrm{Cr}, \mathrm{Hg})$ usage (PACYNA et al., 2009; PACYNA et al., 2011) causing a serious strain on all levels of ecosystems, including raptors (STANKOVIC et al., 2013; KALISINSKA et al., 2014). The wide use of lead bullets by hunters in many countries world-wide (FISHER et al., 2006) is another important source of contamination of heavy metals in birds and their predators. The aim of the present study was to determine $\mathrm{Pb}, \mathrm{Cd}, \mathrm{Ni}$, $\mathrm{Cr}$ and $\mathrm{Hg}$ concentrations in livers of six raptor species nesting in East Poland. We hypothesized that these raptor species show different levels of heavy metal burdens due to differences in habitat selection and prey. 


\section{MATERIALS AND METHODS}

The investigated material consisted of the livers (collected from 58 specimens) of the following raptor species: Common buzzard Buteo buteo (31 specimens), Sparrowhawk Accipiter nisus (10), Goshawk Accipiter gentilis (9), Marsh harrier Circus aeruginosus (3), Common kestrel Falco tinnunculus (3) and White-tailed eagle Haliaeetus albicilla (2). The studied birds originated from different habitats in Eastern Poland (Rzeszów, Białystok, Lublin and Warsaw regions). The livers used in this study were obtained from wounded raptors delivered to rehabilitation centres or veterinary clinics close to raptor nesting sites between 2009 and 2012. The raptors either died despite persistent veterinary treatment, or they were untreatable upon delivery and were administered lethal injection. The raptors' total stay in the clinics or rehabilitation centres did not exceed seven days. Following extraction, the livers were stored in freezers at $-30^{\circ} \mathrm{C}$. Prior to measurement, the livers were freeze-dried and ground in a ceramic mortar. All glassware and utensils were rinsed with tap water, soaked in an acid bath $(5 \mathrm{M}$ $\mathrm{HNO}_{3}$ ) for $24 \mathrm{~h}$, rinsed with demineralised water and dried under a laminar flow hood before use, to minimise the risk of any metal contamination. Weighed portions of the samples $(500 \pm 1 \mathrm{mg})$ were dissolved with $10 \mathrm{~mL}$ of concentrated $\mathrm{HNO}_{3}$ (Sigma Aldrich) and subjected to wetashing. Mineralisation was carried out using the Microwave Digestion System with optical temperature and pressure monitoring of each individual sample during acid digestion (Berghof Speedwave) in Teflon vials (DAP 100 type). The mineralization process was conducted according to the following scheme: $15 \mathrm{~min}$ of temperature rise from room temperature up to $140^{\circ} \mathrm{C}, 5 \mathrm{~min}$ at $140^{\circ} \mathrm{C}, 5 \mathrm{~min}$ heating from $140^{\circ} \mathrm{C}$ up to $170^{\circ} \mathrm{C}, 15$ min at $170^{\circ} \mathrm{C}$, followed by cooling down to room temperature (variable time). The pressure over the whole mineralization process did not exceed 12 bar. After completion of the mineralization process a clear solution was obtained, which was made up to $50 \mathrm{~mL}$ with demineralised water (ELGA Pure Lab Classic). In this study,
ICP-OES (Inductively Coupled Plasma Optical Emission Spectrometry) from Thermo Scientific iCAP Series 6500, equipped with a charge injection device (CID) detector was used for element determination. The spectrometer was controlled by the PC-based iTEVA software. The following instrumental parameters were set: RF power generator $1150 \mathrm{~W}, \mathrm{RF}$ frequency generator of $27.12 \mathrm{MHz}$, coolant gas flow rate $16 \mathrm{~L} \cdot \mathrm{min}^{-1}$, carrier gas flow rate $-0.65 \mathrm{~L} \cdot \mathrm{min}^{-1}$, auxiliary gas flow rate $-0.4 \mathrm{~L} \cdot \mathrm{min}^{-1}$, maximal integration time - $15 \mathrm{~s}$, pump rate $-50 \mathrm{rpm}$, viewing configuration - Axial, replicate - 3, Flush time - $20 \mathrm{~s}$. Analityk - 47: ${ }^{27} \mathrm{Al},{ }^{75} \mathrm{As},{ }^{111} \mathrm{Cd}$, ${ }^{52} \mathrm{Cr},{ }^{208} \mathrm{~Pb},{ }^{55} \mathrm{Mn},{ }^{201} \mathrm{Hg},{ }^{60} \mathrm{Ni},{ }^{45} \mathrm{Sc},{ }^{79} \mathrm{Se},{ }^{88} \mathrm{Sr},{ }^{51} \mathrm{~V}$, ${ }^{6} \mathrm{Zn}$ in $10 \% \mathrm{HNO}_{3}-100 \mathrm{mg} \cdot \mathrm{kg}^{-1}$, multi-element stock solution (Inorganic Ventures) was used as standard.

Redundancy analysis (RDA) was used to establish the relation between heavy metal concentrations and the food habits of the different raptor species. The data required for RDA analysis to rank the habitat and trophic preferences of studied raptors were taken from the literature (CRAMP \& SimMONS, 1980; NeWTON, 1986; WitKOWSKI, 1989; VILlAGE, 1990; ZACCARONI et al., 2008). For statistical analyses, median values were compared using Mann-Whitney and Kruskall-Wallis $\mathrm{H}$ tests (SOKAL \& ROHLF, 1981). Statistical calculations were performed with Statistica, while Canoco 4.5 software was used to visualize some statistical results (TER BRAAK \& ŠMILAUER, 2002).

Metal concentrations are expressed in $\mathrm{mg} / \mathrm{kg}$ dry weight (dw). If literature data were expressed as wet mass of a sample, a conversion factor of 4.0 from a wet weight (ww) to a dry mass of liver was used, according to KALISINSKA et al. (2004). Liver lead concentrations $\geq 6 \mathrm{mg} / \mathrm{kg}$ dw were considered to be diagnostic of elevated exposure resulting in subclinical toxicity. Liver lead concentrations $\geq 15 \mathrm{mg} / \mathrm{kg}$ dw were considered as diagnostic of lead poisoning (FRANSON, 1996). Acute lead poisoning has been observed when liver concentrations exceed $30 \mathrm{mg} / \mathrm{kg} \mathrm{dw}$. The background levels of lead are usually far 
below $6 \mathrm{mg} / \mathrm{kg}$ dw (MARTIN et al., 2008). In the case of cadmium, other authors (BURGAT, 1990; BATTAGLIA et al., 2005) suggested that Cd levels $\geq 3 \mathrm{mg} / \mathrm{kg} \mathrm{dw}$ in liver might indicate increased environmental exposure.

\section{RESULTS}

\section{Trends in concentrations}

RDA analyses were performed taking feeding ecology into account, more specifically the type of preferred food and the foraging area. Among the analysed variables, only a food preference for small birds (Food SB) had a significant relationship with lead and mercury concentrations (Lambda-A: 0.09, $\mathrm{F}=5.42, \mathrm{p}=0.01$; Fig.1). The RDA analyses also showed that elevated concentrations of chromium and mercury were related to feeding on small birds (passerines) as is obvious in the case of Sparrowhawks (Fig. 1; Table 2). Prey captured from water was not a major source of mercury for any of the studied raptors (Fig.1). Feeding on larger avian prey seemed to prevent mercury accumulations, as in Goshawks in contrast to other raptors feeding on small birds. The RDA also showed that investigated individuals with larger body masses tended to accumulate less mercury (for example Common buzzard and White-tailed eagle) (Fig. 1). As is obvious from Fig. 1, the elevated concentrations of cadmium and lead corresponded mostly to the consumption of small mammals as well as to an increasing consumption of medium sized mammals, carrion and game. Buzzards were the only raptor species showing any effect for lead.

\section{Concentrations levels in livers of raptors}

The measured concentrations of the various heavy metals in livers of the investigated raptors are presented in Table 1.

Regarding cadmium, mean concentrations of this metal ranged from 0.282 to $0.786 \mathrm{mg} /$ $\mathrm{kg} \mathrm{dw}$ (Table 1), with a maximum of 3.425 $\mathrm{mg} / \mathrm{kg} \mathrm{dw}$ in one Buzzard. There were no significant differences in hepatic concentrations of cadmium between Goshawks, Sparrowhawks and Buzzards (Kruskall-Wallis H-test: $\mathrm{H}=0.719$, $\mathrm{df}=2, \mathrm{~N}=50, \mathrm{p}=0.699$ ). The highest mean level of chromium was also found in Sparrowhawks (Table 1). Significant differences in the hepatic level of $\mathrm{Cr}$ were observed between Goshawks and Sparrowhawks (Mann-Whitney U test: $\mathrm{Z}=$ $\left.3.67, \mathrm{n}_{1}=10, \mathrm{n}_{2}=9, \mathrm{p}=0.00024\right)$ (Table 1).

The highest individual level of mercury (11.99 $\mathrm{mg} / \mathrm{kg}$ ) was found in a Sparrowhawk. The mean hepatic concentrations of $\mathrm{Hg}$ in Goshawks and buzzards were generally much smaller than in Sparrowhawks (Table 1; and statistically significant differences in the concentrations of mercury were found between the two hawk species of the genus Accipiter $s p$. studied here (Mann-Whitney U test: $\mathrm{Z}=3.18, \mathrm{n}_{1}=10, \mathrm{n}_{2}=9$, $\mathrm{p}=0.004)$.

Mean levels of nickel varied between 0.234 and $0.343 \mathrm{mg} / \mathrm{kg} \mathrm{dw}$, for White-tailed eagles and kestrel, respectively (Table 1 ). An equally narrow range of Ni concentrations was also observed in Goshawks, Sparrowhawks and Buzzards and, similarly to cadmium, no significant differences were observed between these species (KruskallWallis H-test: $\mathrm{H}=0.777$, $\mathrm{df}=2, \mathrm{~N}=50, \mathrm{p}=$ 0.686). Mean hepatic concentrations of lead were significantly lower in Sparrowhawks than in buzzards (Table 1; Mann-Whitney $U$ test: $Z=$ $\left.3.95, \mathrm{n}_{1}=10, \mathrm{n}_{2}=31, \mathrm{p}=0.00008\right)$. In Buzzards, we found two cases with $\mathrm{Pb}$ concentrations of 8.61 and $8.58 \mathrm{mg} / \mathrm{kg} \mathrm{dw}$, respectively. Such concentrations are considered to be diagnostic of elevated lead exposure, resulting in subclinical toxicity. In a single liver from this species, the hepatic lead level reached $15.31 \mathrm{mg} / \mathrm{kg} \mathrm{dw}$ indicating lead poisoning.

\section{DISCUSSION}

Our study shows that prey preference has an effect on the heavy metal load in raptor species. Below, we compare our results to those of other regions for each heavy metal. 
믈 믕 要 8 : $3 \%$ 国 흉 耐 흥 을 政 (5) 들 원 क्ष 은 它

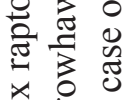
중 tक

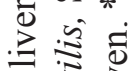
要

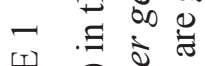

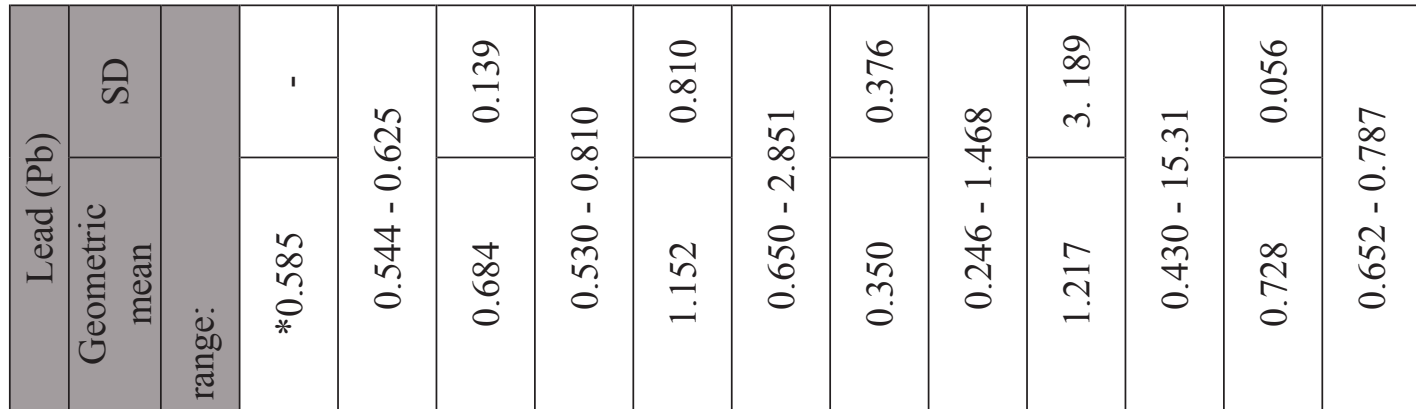

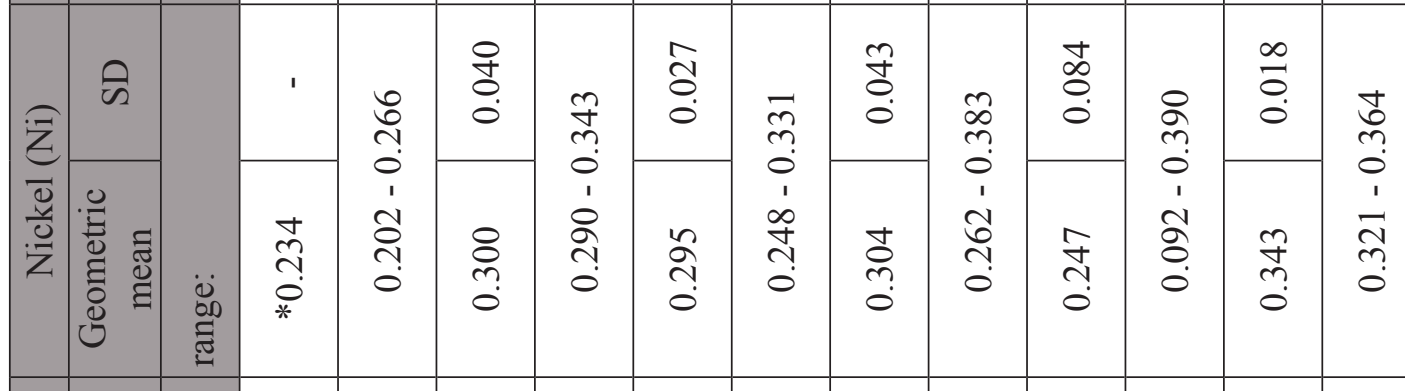

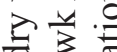
of so है 玹

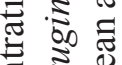
을 药 造

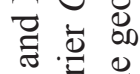
窟 호들

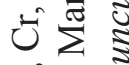
Uंख

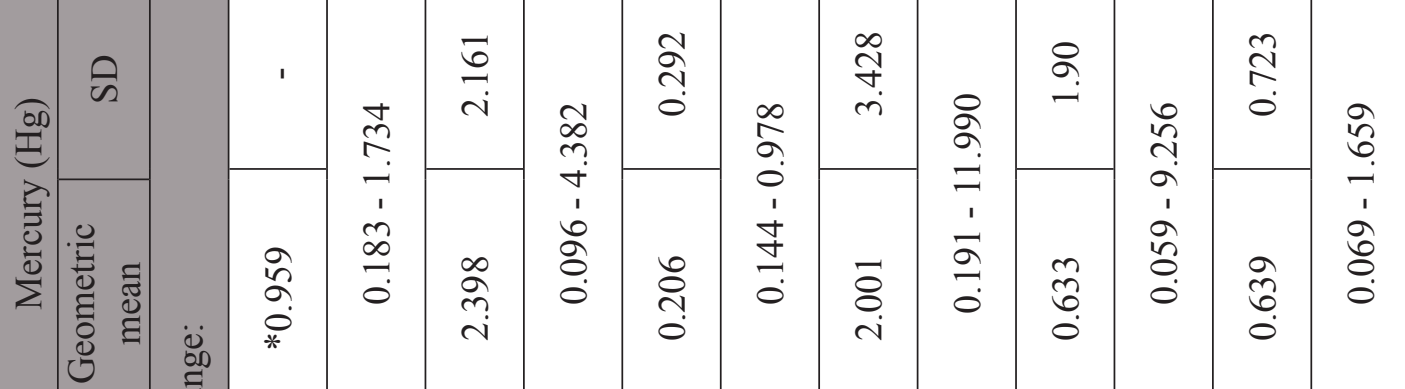

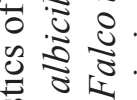
政 을

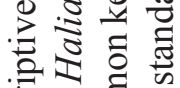

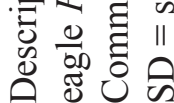

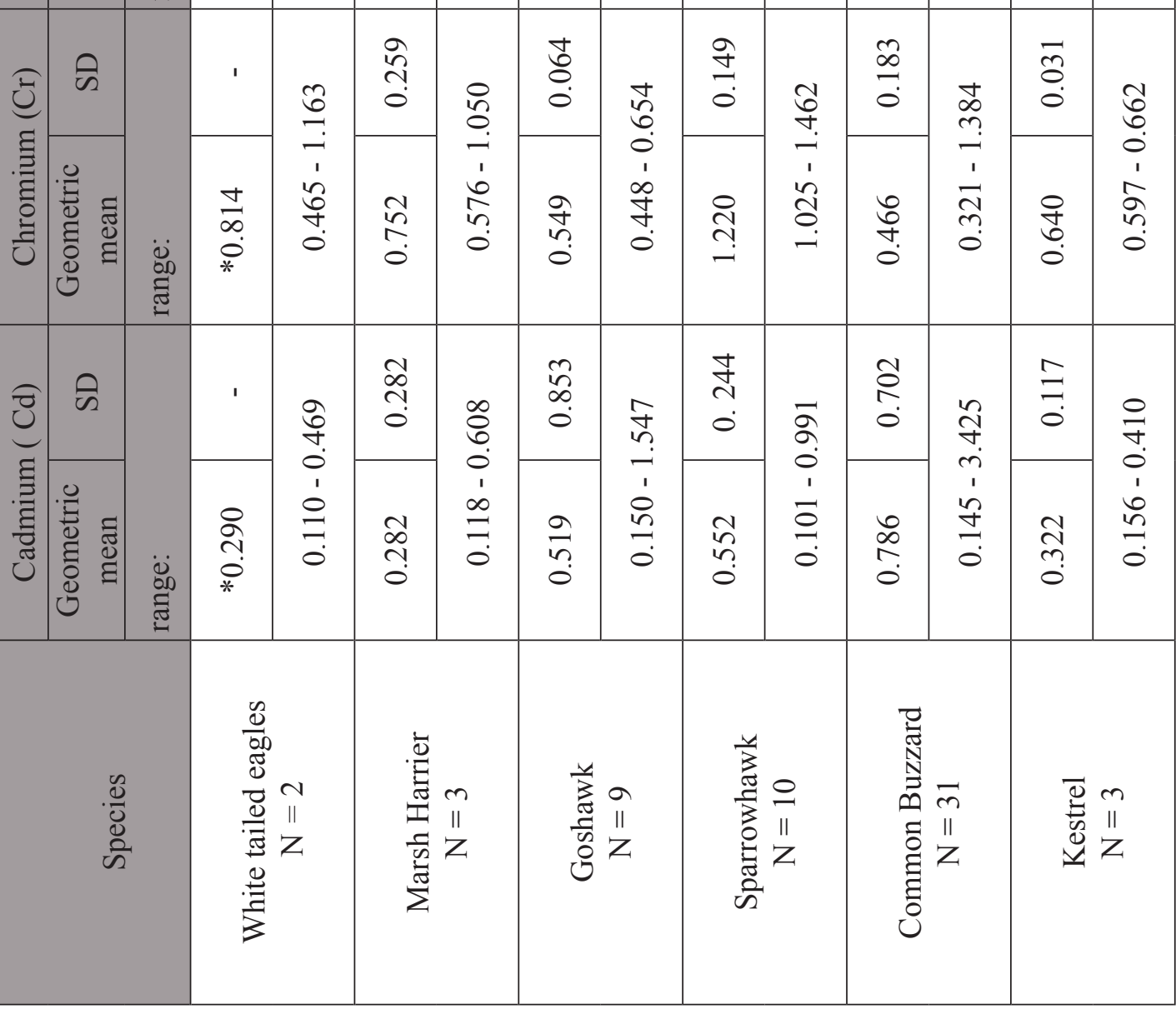




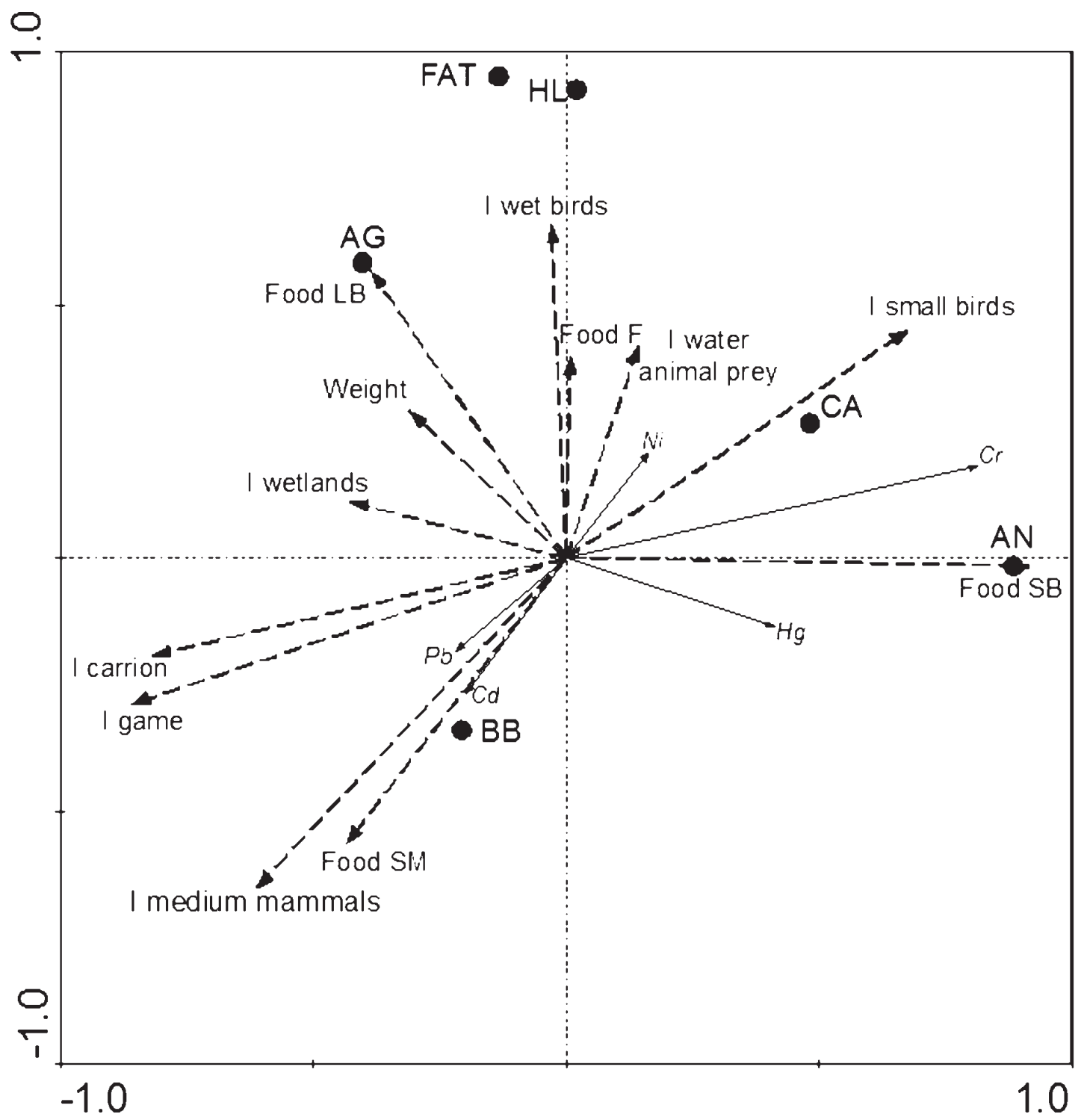

Fig.1. - Results of redundancy analysis (RDA) showing the effect of habitat parameters (dotted lines) on the concentration of heavy metals in the liver of raptors. Eigenvalues: axis $1=0.105$; axis $2=0.029$.

Abbreviations and scales used for analysis:

Species: $\mathrm{HL}=$ White-tailed eagle Haliaeetus albicilla, $\mathrm{CA}=$ Marsh harrier Circus aeruginosus, $\mathrm{AG}=$ Goshawk Accipiter gentilis, $\mathrm{AN}=$ Sparrowhawk Accipiter nisus, $\mathrm{BB}=$ Common buzzard Buteo buteo, $\mathrm{FAT}=\mathrm{Common}$ kestrel Falco tinnunculus.

Food preferences: Food $\mathrm{F}=$ fish, Food $\mathrm{SM}=$ small mammals, Food $\mathrm{SB}=$ small birds, Food LB = large birds. Importance of wetlands for foraging (I wetlands): $1=$ marginal, $2=$ medium, $3=$ high, $4=$ very high. Importance of game in food (I game): $0=$ none, $1=$ marginal, $2=$ medium.

Importance of carrion of big and medium mammals in food (I carrion), importance of big wetland birds in food (I wet birds) and importance of small birds in food (I small birds): $0=$ none, $1=$ marginal, $2=$ medium, $3=$ high. Importance of medium size mammals in food (I medium mammals): $0=$ none, $1=$ marginal, 2 - medium. Importance of water animal prey (I water animal prey): $1=$ small, $2=$ medium, $3=$ big.

Weight: bird mass [kg], according to CRAMP \& SiMMONS (1980). 
TABLE 2

Results of forward selection of habitat parameters. Variables with $\mathrm{P}<0.05$ were only included.

\begin{tabular}{|c|c|c|c|}
\hline Variable & Lambda-A & F & P \\
\hline Food preferences small birds (Food SB) & 0.09 & 5.42 & 0.010 \\
\hline
\end{tabular}

\section{Pb hepatic concentrations and incidence of raptors with $\geq 6 \mathrm{mg} / \mathrm{kg} \mathrm{dw}$ of lead}

The RDA clearly shows that foraging on carrion and game causes elevated lead accumulation in the livers of some examined raptors, and this pattern was strongest for Buzzards (Fig. 1). It can be explained by changes in Buzzard hunting behaviour and the substitution of Common voles Microtus arvalis with other prey sources (JEDRZEJEWSKA \& JEDRZEJEWSKI, 1998; VALKAMA et al., 2005; WUCZYNSKI, 2005; WIKAR et al., 2008). During the winter period, when availability of voles is limited because of snow cover, Buzzards may exploit wounded game or their carrion. Injured or dead game species with embedded or ingested lead may also become more easily available to raptors. On the whole, in our survey only three $(9.7 \%)$ of 31 examined Buzzards revealed hepatic $\mathrm{Pb}$ concentrations $\geq 6 \mathrm{mg} / \mathrm{kg} \mathrm{dw}$. Other researchers (BATTAGLIA et al., 2005; ZACCARONI et al., 2008) found similar hepatic concentrations and proportions of birds with lead concentrations $\geq 6 \mathrm{mg} / \mathrm{kg} \mathrm{dw}$. Only one (3.2\%) of the 31 Buzzards examined in our study had $>15 \mathrm{mg} / \mathrm{kg}$ of $\mathrm{Pb} \mathrm{dw}$ in its liver. Similar limited numbers of Buzzards with such hepatic lead concentrations were reported in W Europe by other authors (PAIN \& AMIARD-TRIQUET, 1993; PAIN et al., 1995).

Goshawk and Sparrowhawk generally do not scavenge frequently (ZIESEMER, 1983; NEWTON, 1986). Lead poisoning among free ranging Goshawks is rare indicating that these hawks seem to be at low risk to lead exposure (PAIN \& Amiard-Triquet, 1993). In Spain, CAStro et al. (2011) described median lead concentration of $0.480 \mathrm{mg} / \mathrm{kg} \mathrm{dw}$ for male and $0.798 \mathrm{mg} / \mathrm{kg} \mathrm{dw}$ for female Goshawks, respectively. Goshawks examined in Germany (KENNTNER et al., 2003) accumulated, on average, $1.19 \mathrm{mg} / \mathrm{kg}$ ww of lead $(4.76 \mathrm{mg} / \mathrm{kg} \mathrm{dw})$ while their median concentration was up to $0.133 \mathrm{mg} / \mathrm{kg} \mathrm{ww}(0.532$ $\mathrm{mg} / \mathrm{kg} \mathrm{dw}$ ). The $\mathrm{Pb}$ levels measured in this study for Goshawks in East Poland were higher, suggesting that the more severe winters in East Poland as compared to Germany (Wos, 1999; BLAZEJCZYK, 2006) could increase scavenging behaviour in these birds.

In Sweden, $18(15.5 \%)$ of 116 White-tailed eagle liver samples had $\mathrm{Pb}$ concentrations $>6 \mathrm{mg} / \mathrm{kg} \mathrm{dw}$ with median concentrations of $0.601 \mathrm{mg} / \mathrm{kg} \mathrm{dw}$ (range: $0.03-154.0 \mathrm{mg} / \mathrm{kg} \mathrm{dw}$ ) (Helander et al., 2009). None of the Whitetailed eagles examined in this study had $\mathrm{Pb}$ hepatic concentrations $>6 \mathrm{mg} / \mathrm{kg} \mathrm{dw}$. This is consistent with the results of the performed RDA analysis illustrating the importance of fish in the overall prey as opposed to individuals that heavily exploit waterfowl and carrion. VAN RIJN et al. (2010) and NADJAFZADEH et al. (2013) proposed that White-tailed eagles respond to availability of fish. When the availability of fish sharply declines, eagles switch to waterfowl and carrion. The consumption of game carrion increases during autumn and winter and is correlated to a concomitant seasonal increase in the incidence of lead poisoning of eagles (HELANDER et al., 2009; NADJAFZADEH et al., 2013), an effect that we did not observe.

The RDA analysis also showed that the food preferences of Marsh harriers obviously allow them to avoid the accumulation of lead because their diet is mainly based on small or medium sized mammals, wetland birds, and carrion of fish (WITKOWSKI, 1989). Marsh harriers examined in this study accumulated less $\mathrm{Pb}$ in their livers 
than Spanish raptors (with lead concentrations of $2.02-8.75 \mathrm{mg} / \mathrm{kg} \mathrm{dw}$; MATEO et al., 1999). One individual Marsh harrier found dead in France with an ingested lead bullet had hepatic $\mathrm{Pb}$ concentrations of $54.9 \mathrm{mg} / \mathrm{kg}$ dw (PAIN et al., 1993). Contrary to Western Europe (PAIN et al., 1995; PAIN et al., 1997; MATEO et al., 1999; MATEO, 2009), our study reveals that for Marsh harriers from Eastern Poland, hunted game not retrieved by hunters is not an important food source.

\section{Cadmium levels and its sources}

Cadmium concentrations in birds are generally reported to be the lowest in livers, while being intermediate in muscle tissue and highest in kidneys (GARCIA-FERNANDEZ et al., 1996; BATTAGLiA et al., 2005; BINKOWSKI et al., 2013). However, we assumed that using liver to monitor $\mathrm{Cd}$ exposure is still relevant because it accumulates about half of the total $\mathrm{Cd}$ body burden and $\mathrm{Cd}$ is stable in the liver (as liver is resistant to cadmium toxic effects; BURGAT, 1990; BAtTAgLiA et al., 2005). The increasing concentration of $\mathrm{Cd}$ in Buzzard livers reported here could be directly related to their feeding preferences including voles. This is obvious from the results of the RDA analyses (Fig. 1) revealing a strong statistical effect of feeding on small mammals for elevated Cd levels.

Such a pattern can probably be attributed to the effect of the trophic preferences of common voles seized mainly on fields contaminated with fertilizers containing Cd (BEYER, 2000; FINNISH ENVIRONMENT INSTITUTE, 2000). Like other Eastern European countries, another significant source of $\mathrm{Cd}$ in East Poland is coal combustion (low emission from coal-burning stoves; PACYNA et al., 2011; SESHADRI et al., 2010). In our study, this threshold value $>3.0 \mathrm{mg} / \mathrm{kg} \mathrm{dw}$ was exceeded only in a single Buzzard out of 31 specimens. The $\mathrm{Cd}$ concentrations in Buzzards from Northern Italy (median: $0.01 \mathrm{mg} / \mathrm{kg} \mathrm{dw}$, range: $0.017-2.02 \mathrm{mg} / \mathrm{kg} \mathrm{dw}$; BATTAGLIA et al., 2005), Portugal (mean $0.322 \mathrm{mg} / \mathrm{kg} \mathrm{dw}$, median:
$0.184 \mathrm{mg} / \mathrm{kg}$; CARNEIRO et al., 2014) and Spain (mean $0.364 \mathrm{mg} / \mathrm{kg}$ dw in males and $0.410 \mathrm{mg} / \mathrm{kg}$ $\mathrm{dw}$ in females, respectively; CASTRO et al. 2011) were much lower than in our study. Interestingly, Polish Buzzards previously examined by us accumulated clearly more $\mathrm{Cd}$, namely on average $1.01 \mathrm{mg} / \mathrm{kg}$ dw Cd (10 specimens; KomosA et al., 2012).

Two other studies reported lower liver cadmium concentrations than our study. KENNTNER et al. (2003) examined specimens of Goshawk from Germany, which had overall mean cadmium concentrations of $0.06 \mathrm{mg} / \mathrm{kg} \mathrm{ww}$ and mean liver concentrations of $0.24 \mathrm{mg} / \mathrm{kg} \mathrm{dw}$ while CASTRO et al. (2011) reported a median hepatic $\mathrm{Cd}$ concentration of $0.146 \mathrm{mg} / \mathrm{kg} \mathrm{dw}$ (male) and $0.154 \mathrm{mg} / \mathrm{kg} \mathrm{dw}$ (females), respectively. Interestingly, in Sweden, a similar hepatic cadmium level $(0.80 \mathrm{mg} / \mathrm{kg} \mathrm{dw})$ to Goshawks from our studies was found for Peregrines (Falco peregrinus) feeding on birds of bigger sizes (EK et al., 2004) like Goshawks do. FALANDYSZ et al. (2001) reported a two-fold lower Cd level $(0.15 \mathrm{mg} / \mathrm{kg} \mathrm{dw})$ in livers of ten Baltic Whitetailed eagles than our measurements for the same species (Table 1).

\section{Mercury levels and its sources}

The RDA showed that consumption of small birds such as passerines can be a source of mercury contamination (Fig. 1). This is so because higher concentrations of mercury are strongly dependent on the extent of feeding on passerines or grains dressed with $\mathrm{Hg}$-based fungicides. Such a correlation was strongest for Sparrowhawks. Earlier reports (JOHNELS et al., 1979; SOLONEN \& LODENIUS, 1984) showed that granivorous birds can be the main cause of $\mathrm{Hg}$ accumulation in Sparrowhawks because they constitute approximately $1 / 5$ of the prey consumed during the breeding season. Such contamination as reported here may indicate a return to dressed seed usage in Poland or neighbouring countries. For Buzzards examined in Spain, median hepatic mercury concentration 
amounted to $1.96 \mathrm{mg} / \mathrm{kg}$, both for males and females (CASTRO et al., 2011), which was three times more than the concentrations found in the current study. Also livers of Buzzards from Czech Republic showed a median $\mathrm{Hg}$ level of $2.61 \mathrm{mg} / \mathrm{kg} \mathrm{dw}$ (HousEROVA et al., 2005) which was 3-fold higher than that determined in our survey. For Spanish Goshawks, CASTRO et al. (2011) measured median $\mathrm{Hg}$ hepatic levels of $0.236 \mathrm{mg} / \mathrm{kg} \mathrm{dw}$ and $0.182 \mathrm{mg} / \mathrm{kg} \mathrm{dw}$, respectively, for males and females, which are far below our measurements. These estimates may reflect a preference for seizing avian prey of smaller size, including passerines feeding on illegally dressed grain. This may also explain why maximal $\mathrm{Hg}$ levels were 8-fold higher in males than females (CASTRO et al., 2011). In our study, the strong correlation between mercury and the consumption of small birds in the RDA analyses also implies that consumption of bigger avian prey by Goshawks allows them to avoid the accumulation of large amounts of mercury in the livers, in contrast to the Sparrowhawks specialized in catching small birds (NEWTON, 1986). Goshawk individuals examined in Germany had very similar levels of hepatic mercury to those in the current study, with median values of $0.069 \mathrm{mg} / \mathrm{kg}$ ww (about 0.276 $\mathrm{mg} / \mathrm{kg}$ dw; KENNTNER et al., 2003).

Many researchers have pointed out the disastrous state of waterbodies and the sea and the resulting contamination of water prey as a mercury source in raptors (FALANDYSZ et al., 2001; KALISINSKA et al., 2014). However, during the last years, water quality has very much improved. When examining livers of eight White-tailed eagles from south Baltic coasts, FALANDYSZ et al. (2001), found a mean value of $5.8 \mathrm{mg} / \mathrm{kg} \mathrm{Hg}$ which was 6 -fold higher than our findings (Table 1). Recent analysis of White-tailed eagles (KALISINSKA et al., 2014) showed that mercury contamination in the Polish Baltic region has been reduced as a result of a decrease of heavy metal emissions. This was confirmed by studies on other biota from the same region (GUSEV, 2013; NYBERG et al., 2013). As demonstrated by our RDA analysis, water animals as prey were also not a significant source of contamination for Polish raptors.

\section{Chromium and nickel}

For Marsh harrier, kestrel, Buzzard and Sparrowhawk from south Italy, the mean hepatic concentrations of chromium never exceeded $0.40 \mathrm{mg} / \mathrm{kg} \mathrm{dw}$ (ZACCARONI et al., 2008). In the same study, Tawny owls (Strix aluco), which are known to prey frequently on passerines, had mean hepatic concentrations slightly exceeding $0.30 \mathrm{mg} / \mathrm{kg} \mathrm{dw}$. A similar value was determined from another study from north Italy on the Little owl (Athene noctua) for which a concentration of $0.29 \mathrm{mg} / \mathrm{kg} \mathrm{ww}$ (i.e. about $1.16 \mathrm{mg} / \mathrm{kg} \mathrm{dw}$.) was determined. Both estimates from Italy are very similar to the levels obtained for Sparrowhawks in this study. An important diet component of Italian Little owls is passerines (ZACCARONI et al. 2003). This finding fits our data as the RDA analysis showed that consumption of passerines is not only correlated to elevated concentrations of mercury but also of chromium (Fig. 1). FALANDYSZ et al. (2001) measured mean $\mathrm{Cr}$ concentration of $0.087 \mathrm{mg} / \mathrm{kg} \mathrm{dw}$ in three specimens of White-tailed eagles from the south Baltic, which is considerably less than our results from inland White-tailed eagles. MANNING et al. (2000) reported an even lower Cr hepatic value for a single Australian White-bellied sea-eagle (Haliaeetus leucogaster) of $0.04 \mathrm{mg} / \mathrm{kg}$ ww (i.e. about $0.16 \mathrm{mg} / \mathrm{kg} \mathrm{dw}$ ). In contrast, for Whitebacked vulture (Pseudogyps africanus) $(\mathrm{n}=5$ specimens) from the Republic of South Africa, VAN WYK et al. (2001) estimated on average $19.57 \mathrm{mg} / \mathrm{kg} \mathrm{dw}$ of hepatic $\mathrm{Cr}$, which is higher than what we measured.

Sparrowhawks and Goshawk from our study, being specialised in seizing birds, accumulated almost similar average levels of $\mathrm{Ni}(0.3 \mathrm{mg} /$ $\mathrm{kg} \mathrm{dw}$ ). A single specimen of Peregrine (Falco peregrinus) also preying on birds from NW Poland had hepatic Ni concentration of only $0.107 \mathrm{mg} / \mathrm{kg}$ dw (KALISINSKA et al., 2008). FALANDYSZ et al. (2001) showed that livers of 
White-tailed eagles had 56-fold higher hepatic nickel concentrations $(13.0 \mathrm{mg} / \mathrm{kg} \mathrm{dw})$ than our findings. It seems that White-tailed eagles from East Poland have less opportunities to prey in highly mercury- and nickel-contaminated areas than raptors from the south Baltic Sea coast.

\section{CONCLUSIONS}

We could show that food preferences of raptors can strongly influence the load of heavy metals as is, for example, evidenced by the elevated concentrations of $\mathrm{Hg}$ and $\mathrm{Cr}$ in Sparrowhawks. This can be explained by their preying on small birds. Similarly, through scavenging on game and its carrion, Buzzards are more exposed to $\mathrm{Pb}$, probably originating from lead bullets of hunters. That the impact of human activities on heavy metal accumulation in raptors can also be reduced, is illustrated by our data from White eagles preying on fish, where the amount of $\mathrm{Hg}$ contamination in aquatic habitats has decreased significantly in the last years.

\section{ACKNOWLEDGEMENTS}

This research was funded from statutory funds of the Institute of Agrophysics in Lublin and of the University of Life Sciences in Lublin.

\section{REFERENCES}

BATTAGLiA A, GHIDINI S, CAMPANINI G \& SPAGGIARI $\mathrm{R}$ (2005). Heavy metal contamination in little owl (Athene noctua) and common buzzard (Buteo buteo) from Northern Italy. Ecotoxicology and Environmental Safety, 60: 61-66.

BEYER WN (2000). Hazards to wildlife from soil-borne cadmium reconsidered. Journal of Environmental Quality, 29: 1380-1384.

BINKOWSKI LJ, STAWARZ RM \& ZAKRZEWSKI M (2013). Concentrations of cadmium, copper and zinc in tissues of mallard and coot from southern Poland. Journal of Environmental Science and Health, Part B, 48: 410-415.
BLAZEJCZYK K (2006). Climate and bioclimate of Poland. In: DEGORSKI M (ed.). Natural and human environment of Poland. A geographical overview. Polish Academy of Sciences. IGSO, PAS, Warsaw: 31-48.

BURGAT V (1990). Un micropollutant: le cadmium Bulletin Mensuel de l'Office National de la Chasse 146: 40-42.

Carneiro M, Colaco B, Brandao R, Ferreira C, Santos N, Soeiro V, Colaco A, Lavín S, JoAo Pires M, Oliveira PA \& LAVIN S (2014). Biomonitoring of heavy metals $(\mathrm{Cd}, \mathrm{Hg}$, and $\mathrm{Pb})$ and metalloid (As) with the Portuguese common buzzard (Buteo buteo). Environmental Monitoring and Assessment, 186: 7011-7021.

Castro I, Aboal JR, Fernandez JA \& CARbalLEIRA A (2011). Use of Raptors for Biomonitoring of Heavy Metals: Gender, Age and Tissue Selection. Bulletin of Environmental Contamination and Toxicology, 86: 347-351.

CRAMP S, SIMMONS KEL (1980). Handbook of the birds of Europe, the Middle East and North Africa: the birds of the Western Palearctic: hawks to bustards Vol 2. Oxford University Press, Oxford.

EK KH, MORRISON GM, LindBERG P \& RAUCH S (2004). Comparative Tissue Distribution of Metals in Birds in Sweden Using ICP-MS and Laser Ablation ICP-MS. Bulletin of Environmental Contamination and Toxicology, 47: 259-269.

FALANDYSZ J, ICHIHASHI H, SZYMCZAK K, YAMASAKI S \& MIZERA T (2001). Metallic elements and metal poisoning among White tailed sea eagles from the Baltic Sea. Marine Pollution Bulletin, 42: 1190-1193.

FINNISH ENVIRONMENT INSTITUTE (2000). Cadmium in fertilizers risks to human health and the environment, Study Report. Finnish Ministry of Agriculture and Forestr, Helsinki. (Internet addres: http://ec.europa.eu/enterprise/sectors/ chemicals/)

Fisher IJ, PAIN DJ \& THOMAS VG (2006). A review of lead poisoning from ammunition sources in terrestrial birds. Biological Conservation, 131: 421-432.

FRANSON JC (1996). Interpretation of tissue lead residues in birds other than waterfowl. In: BEYER WN, HEINZ GH \& REDMON-NORWOOD AW (eds), Environmental contaminats in wildlife Interpreting tissue concentrations, CRC Press, Boca Raton: 265-279. 
Garcia-FernandeZ AJ, SANCHEZ-Garcia JA, GOMEZ-ZAPATA M \& LuNA A (1996). Distribution of cadmium in blood and tissues of wild birds. Archives of Environmental Contamination and Toxicology, 30: 252-258.

GOLDEN NH, WARNER SE \& COFFEY MJ (2016). A Review and Assessment of Spent Lead Ammunition and Its Exposure and Effects to Scavenging Birds in the United States. Reviews of Environmental Contamination and Toxicology, 237: 123-19.

GusEV A (2013). Atmospheric emissions of heavy metals in the Baltic Sea region HELCOM Baltic Sea Environment Fact Sheets 2011. (Internet address: http://helcom navigo fi/).

HASCHEK WM, ROUSSEAUX CG \& WALLiG MA (2013). Haschek and Rousseaux's handbook of toxicologic pathology. Academic Press, San Diego.

Helander B, AXelsson J, Borg H, HOLM K \& BignerT A (2009). Ingestion of lead from ammunition and lead concentrations in whitetailed sea eagles (Haliaeetus albicilla) in Sweden. Sciences of the Total Environment, 407: 55555563.

Houserova P, Hedbavny J, Matejicek D, KracMAR S, SitKo J \& KUBAN V (2005). Determination of total mercury in muscle, intestines, liver and kidney tissues of cormorant (Phalacrocorax carbo), great crested grebe (Podiceps cristatus) and Eurasian buzzard (Buteo buteo). Veterinary Medicine (Prague), 50: 61-68.

JEDRZEJEWSKA B \& JEDRZEJEWSKI W (1998) Predation in Vertebrate Communities. The Białowieża Primeval Forest as a case study. Springer Verlag, Berlin.

Johnels A, TYler G \& Westermark T (1979). A history of mercury levels in Swedish fauna. Ambio, 8: 160-168.

KALISINSKA E, LISOWSKI P, CZERNOMYSY-FUROWICZ D \& KAVETSKA KM (2008). Serratospiculiasis, mycosis, and hemosiderosis in wild peregrine falcon from Poland -Case report. Bulletin of the Veterinary Institute in Pulawy, 52: 75-79.

Kalisinska E, SALicki W, Myslek P, KaVetska KM \& JACKOWSKI A (2004). Using the mallard to biomonitor heavy metal contamination of wetlands in North-Western Poland. Sciences of the Total Environment, 320: 145-161.

KALISINSKA E, GORECKI J, LANOCHA N, OKONSKA A, Melgarejo JB, Budis H, Rzad I \& Golas J (2014). Total and Methylmercury in Soft Tissues of White-Tailed Eagle (Haliaeetus albicilla) and Osprey (Pandion haliaetus) Collected in Poland. Ambio, 43: 858-870.

KenNTNER N, KRONE O, ALtenKamp R \& TATARUCH F (2003) Environmental contaminants in liver and kidney of free-ranging Northern Goshawks (Accipiter gentilis) from three regions of Germany. Archives of Environmental Contamination and Toxicology, 45: 128-135.

Kitowski I., Sujak A., Wiacek D., Strobel W. \& RYMARZ M (2014). Trace element residues in eggshells of Grey Heron (Ardea cinerea) from colonies of East Poland. North-West Journal of Zoology, 10: 346-354.

Komosa A, Kitowski I \& Komosa Z (2012). Essential Trace $(\mathrm{Zn}, \mathrm{Cu}, \mathrm{Mn})$ and Toxic $(\mathrm{Cd}$, $\mathrm{Pb}, \mathrm{Cr}$ ) Elements in Liver of Birds from Eastern Poland. Acta Veterinaria (Beograd), 62: 579-589.

MANNING T, RosS GA \& SYMONS R (2008). Environmental contaminants in white-bellied seaeagles (Haliaeetus leucogaster) found in Sydney, Australia. Australian Journal Ecotoxicology, 14: 21-30.

Martin PA, CAmpbell D, Hughes K \& MCDaniel (2008). Lead in the tissues of terrestrial raptors in southern Ontario, Canada, 1995-2001. Sciences of the Total Environment, 391: 96-103.

Mateo R, Estrada J, PAQUeT JY, Riera X, DOMinGUEZ L, GUITART R \& MARTNEZ-VILALTA A (1999). Lead shot ingestion by marsh harriers Circus aeruginosus from the Ebro delta, Spain. Environmental Pollution, 104: 435-440.

MATEO R (2009). Lead poisoning in wild birds in Europe and the regulations adopted by different countries. In: WATSON RT, FULLER M, POKRAS M \& HUNT WG (eds), Ingestion of lead from spent ammunition: Implications for Wildlife and Humans, The Peregrine Fund, Boise: 71-98.

NADJAFZADEH M, Hofer H \& Krone O (2013). The link between feeding ecology and lead poisoning in white-tailed eagles. Journal Wildlife Management, 77: 48-57.

Newton I (1986). The Sparrowhawk. T and AD Poyser Ltd., Calton.

Nyberg E, LARSEn MM, Bignert A, BoAlt E \& DANIELSON S (2013). Metals (lead, cadmium and mercury). HELCOM Core Indicator Report. (Internet address: http://helcom fi/)

PACYNA JM, PACYNA EG \& AAS W (2009). Changes of emissions and atmospheric of mercury, lead and cadmium. Atmospheric Environment, 43: 117-127. 
Pacyna J, Steenhuisen F, Wilson S \& Pacyna (2011) Global anthropogenic emissions of mercury to the atmosphere. (Internet address: http://www eoearth org/).

PAIN DJ \& Amiard-TRIQueT C (1993). Lead poisoning in raptors in France and elsewere. Ecotoxicology and Environmental Safety, 25: 183-192.

Pain DJ, Amiard-Triquet C, Baboux C, BurneLeau G, Eon L \& Nicolau-Guillaumet $P$ (1993). Lead poisoning in wild populations of marsh harrier Circus aeruginosus in the Camarque and Charente-Maritime, France. Ibis, 135: 379386.

Pain DJ, Bavoux C \& Burneleau G (1997). Seasonal blood lead concentration in marsh harrier Circus aeruginosus from CharenteMaritime, France: relationship with the hunting season. Biological Conservation, 81: 1-7.

Pain DJ, Sears J \& Newton I (1995). Lead concentration in birds of prey in Britain. Environmetal Pollution, 87: 173-180.

RAJAMANI J, SUBRAMANIAN M (2015). Toxicity Assessment on the Levels of Select Metals in the Critically Endangered Indian White-backed Vulture, Gyps bengalensis, in India. Bulletin of Environmental Contamination and Toxicology, 94: 722-726.

Seshadri B, Bolan NS, NAIDU R \& BRodie KJ (2010). The role of coal combustion products in managing the bioavailability of nutrients and heavy metals in soils. Soil Science and Plant Nutrition, 10: 378-398.

SCHEUHAMMER AM (1987). The chronic toxicity of aluminium, cadmium, mercury, and lead in birds: a review. Environmental Pollution 46: 263-295.

SOKAL FJ \& ROHLF RR (1981). Biometry. Freeman and Company Ltd., New York.

SOLONEN T \& LODENIUS M (1984). Mercury in Finish Sparrowhawks Accipiter nisus. Ornis Fennica, 61: 58-63.

Stankovic S, Kalaba P \& Stankovic AR (2013). Biota as toxic metal indicators, Environmental Chemistry Letters 12: 63-84.

Ter BraAk CJF, Šmilauer P, 2002. CANOCO Reference manual and CanoDraw for Windows User's guide: Software for Canonical Community Ordination (version 4.5). Microcomputer Power, Ithaca, NY, USA.
VAlKama J, Korpimäki E, Arroyo B, Beja P, Bretagnolle V, Bro E, KenWARD R, Manosa S, RedPath SM, Thirgood S \& Vinuela J (2005). Birds of prey as limiting factors of gamebird populations in Europe: a review. Biological Reviews, 80: 171-203.

VAN WYK E, VAN DER BANK FH \& VERDOORN GH (2001). Selected mineral and heavy metal concentrations in blood and tissues of vultures in different regions of South Africa. South African Journal of Animal Sciences, 31: 57-64.

Village A (1990). The Kestrel. T and AD Poyser Ltd., Calton.

WiLliams PL, JAMES RC \& ROBERTS SM (2014). Principles of toxicology: environmental and industrial applications. John Wiley \& Sons, New York.

WiKAR D, CIACH M, BYLICKA M \& BYLICKA M (2008). Changes in habitat use by the Common Buzzard (Buteo buteo L.) during non-breeding season in relation to winter conditions. Polish Journal of Ecology, 56: 119-125.

WITKOWSKI J (1989). Breeding biology and ecology of the marsh harrier Circus aeruginosus in the Barycz Valley, Poland. Acta Ornithologica, 25: 223-320.

Wos A (1999). Climate of Poland. Wydawnictwo Naukowe PWN, Warszawa.

WUCZYŃSKI A (2005). Habitat use and hunting behaviour of Common Buzzards Buteo buteo wintering in south-western Poland. Acta Ornithologica, 40: 147-154.

Zaccaroni A, Amorena M, Naso B, Castellani G, LuCisano A \& Stracciari GL (2003). Cadmium, chromium and lead contamination of Athene noctua, the little owl, of Bologna and Parma, Italy. Chemosphere, 52:1251-1258.

ZaCCARONI A, ANDREANi G, FERRANTE MC, CARPENE E, ISANI G \& LuSIANO A (2008). Metal concentrations in the liver and kidney of raptor species from the Calabria region, Italy. Acta Veterinaria (Beograd), 58: 315-324.

ZIESEMER F (1983). Study on goshawk (Accipiter gentilis) influence on its prey population, Beiträge zur Wildbiologie. Kronshagen, Heft 2. (in German).

Received: March 14th, 2015

Accepted: January 20th, 2016

Branch editor: Roger Huybrechts 